\title{
Passing and Strategic Voting on the U.S. Supreme Court
}

\author{
Timothy R. Johnson \\ James F. Spriggs II \\ Paul J. Wahlbeck
}

\begin{abstract}
Analyzing strategic aspects of judicial decisionmaking is an important element in understanding how law develops. In this article, we examine sophisticated voting on the U.S. Supreme Court by empirically modeling justices' decisions to pass when it is their turn to vote during conference discussions. We argue that, due to the opinion assignment norm, the chief justice may pass when one of the key conditions necessary for sophisticated voting - certainty about the views held by other justices and the agenda - is lacking. By passing, the chief can view his colleagues' votes in order to determine which vote will allow him to assign the majority opinion and, ultimately, forward his policy preferences. Using data from Justice Lewis F. Powell's conference notes, we show that the chief passes for this purpose, and that doing so is an effective strategy. In addition, we show that the senior associate justice in a case, who has a nontrivial chance of assigning the majority opinion, also passes for strategic reasons. As we expect, the data indicate that the remaining associates seem not to pass for strategic purposes.
\end{abstract}

I

$\mathrm{n}$ recent years, studies of law and courts have emphasized that judges are strategic decision makers. A strategic judge is one who understands that law on the books must be translated into law in action. Put another way, strategic judges acknowledge that they cannot act independently as they attempt to establish legal policy.

We appreciate John Jacob's assistance with the papers of Justice Lewis Powell. Johnson thanks the University of Minnesota's Department of Political Science and the MacMillan Travel Grant fund for financial assistance for the data collection, and Matt Roberts, Jeff Hubbard, Dan Carden, and Carey Olney at the University of Minnesota for their research assistance. Spriggs thanks the Academic Senate at the University of California, Davis, for financial support. Previous versions of this article were presented at the 2001 and 2002 annual meetings of the American Political Science Association (APSA) and received the 2002 American Judicature Society Award from the Law and Courts Section of APSA. Please address correspondence to Timothy Johnson, Department of Political Science, University of Minnesota, 1380 Social Science Building, 267 19th Avenue S, Minneapolis, MN 55455; e-mail: tjohnson@polisci.umn.edu; James Spriggs, Department of Political Science, University of California-Davis, Davis, CA 95616; e-mail: jfspriggs@ucdavis.edu; or Paul Wahlbeck, Department of Political Science, George Washington University, Washington, DC 20052; e-mail: wahlbeck@gwu.edu.

Law E Society Review, Volume 39, Number 2 (2005)

(C) 2005 by The Law and Society Association. All rights reserved. 
Thus, a strategic judge's decisions on the bench are influenced in part by the preferences or anticipated choices of other relevant decision makers. While the efficacy of legal policies articulated in decisions depends on the choices made by a panoply of implementers, judges on collegial courts must confront the importance of choices made by their colleagues on the bench. In other words, before issuing a decision a judge must gain the support of his or her colleagues in order to speak for the court.

Viewing judges as strategic actors is important because it sheds light on a judge's most important task: setting legal policy. Law develops as judges make choices in the process of deciding particular cases, and to understand legal development it is critical that we explain judges' decisions. Existing research, for instance, shows that when U.S. Supreme Court justices craft majority opinions they bargain, negotiate, and compromise in an attempt to bring legal policy as close as possible to their preferred alternatives (see Epstein \& Knight 1998; Maltzman et al. 2000). While most research to date has focused on the U.S. Supreme Court (e.g., Caldeira et al. 1999; Epstein \& Shvetsova 2002; Hansford \& Damore 2000), comparative studies of law are ripe for consideration of the strategic elements of judicial decisionmaking (see, e.g., Helmke 2002, 2003; Iaryczower et al. 2002; Epstein et al. 2001). Vanberg (2001), for example, shows that the German Federal Constitutional Court acts strategically when deciding whether to strike down legislation. In addition, state court judges in the United States act strategically in response to whether, and when, they must stand for reelection (Brace \& Hall 1997).

In this article, we explore how justices behave strategically when casting votes at conference. After the Supreme Court hears oral arguments in a case, the justices gather at conference to cast preliminary votes. They express their views and cast their votes, in order of seniority, beginning with the chief justice (CJ) and moving down to the most junior justice. Under this voting rule, the $\mathrm{CJ}$ is the first to cast a vote and, arguably, has the most at stake. Indeed, when the chief is in the conference majority the task of assigning an author to write the majority opinion falls to him. This prerogative helps him influence the Court's agenda by selecting an author whose opinion is close to his own preferences, or who will minimize the prospective policy loss if the chief's preferred outcome does not prevail (Epstein \& Knight 1998; Maltzman et al. 2000). ${ }^{1}$

1 Maltzman et al. (2000) demonstrate that the justice who assigns the opinion has some power to set the agenda for the majority coalition because the writer gets the first move in the bargaining process. The chief exercises this discretion and guides the opinion toward his preferred position by assigning it to ideologically proximate justices, especially in important cases. In other words, although the CJ is constrained by norms, such as the 
Chief Justice Warren Burger was renowned, and even vilified in some quarters, for voting strategically during conference discussions on the Supreme Court in order to control the Court's agenda through opinion assignment. Indeed, Burger is said to have often changed votes to join the majority coalition, cast "phony votes" by voting against his preferred position, and, of particular interest to us here, declined to express a position at conference (see Woodward \& Armstrong 1979; Epstein \& Knight 1998). This behavior led one critical justice to point out that, "all too damned often the Chief Justice will vote with the majority so as to assign the opinion, and then he ends up in dissent" (Schwartz 1990:14). Although many claimed that Burger voted sophisticatedly to manipulate the Court's agenda through opinion assignment, he was probably not the first chief to vote in this manner during conference. ${ }^{2}$ As Murphy hypothesizes of CJs when they were the first to speak and the last to vote, "Thus, before he finally commits himself, he knows where each Justice stands - at least for the present and which side will most probably win. If his own views are going to be in the minority, he can vote with the majority and retain the opinion-assigning authority" (1964:84-5). ${ }^{3}$

This article focuses on one potential form of strategic behavior at conference - a justice's ability to pass, and therefore delay his vote until all the other justices have voted. We argue that the CJ has a unique incentive to pass that derives from the Court's opinion assignment norm. ${ }^{4}$ Indeed, when the chief is uncertain about the final outcome in the case, he can pass in order to view his colleagues' votes. This behavior will help him determine which vote (reverse or affirm) will allow him to assign the majority opinion. While not technically a sophisticated vote, the chief may pass so he can, if necessary, vote against his most preferred alternative during conference in order to move the case outcome to a point that is closer to his preferred goals than if he had voted with the minority.

equitable distribution of assignments, he has the power to choose who will articulate the Court's opinion and the lens through which a case will be decided.

${ }^{2}$ Indeed, Murphy (1964) traces sophisticated voting to control opinion writing to Chief Justice John Marshall. Although short on supporting evidence, some argue that Marshall wrote opinions "even in cases where he dissented" (Schwartz 1993:152).

${ }^{3}$ Since at least the time of John Marshall's tenure on the Court (and through the 1960s), the discussion of a case at conference started with the chief and concluded with the most junior justice, while voting proceeded in the opposite fashion (see Clark 1959). As Justice Brennan describes, "The junior justice votes first and voting then proceeds up the line to the Chief Justice who votes last" (1960:402). Sometime in the mid-1960s, however, this voting rule changed, and both discussion and voting in a case now proceeds based upon seniority, with the chief both discussing a case and voting first (see Rehnquist 2001:254).

${ }^{4}$ The senior associate justice (SAJ) may share this incentive with the $\mathrm{CJ}$, as he frequently assigns opinions when the $\mathrm{CJ}$ does not side with the majority at conference. We explore this possibility below. 
Employing a unique data set constructed from Justice Lewis F. Powell's docket sheets, we demonstrate how the chief can, if necessary, pass for the strategic purpose of moving policy closer to his preferred outcome. These data also allow us to demonstrate the impact of this behavior by determining the extent to which the chief votes with the majority and therefore ultimately assigns the opinion even when the coalition seems ideologically contrary to his preferred outcome.

\section{Sophisticated Voting and the Supreme Court}

Beginning with Farquharson's (1969) Theory of Voting; a host of scholars have employed formal models to demonstrate the theoretical importance of sophisticated voting for understanding interdependent decisionmaking, especially as applied to collegial decisionmaking bodies such as the U.S. Congress (e.g., Kramer 1972; McKelvey \& Niemi 1978; Banks 1985; Denzau et al. 1985). Sophisticated voting occurs when decision makers vote against their most preferred alternative at one stage of a decisionmaking process in order to produce outcomes at later stages that are more preferred. ${ }^{5}$ As Calvert and Fenno put it, sophisticated voting occurs in Congress "when a legislator votes against an amendment that he or she favors in principle, in order to improve the chances for passage of the bill itself" (1994:349). Recent research provides some systematic support for sophisticated voting in Congress (Jenkins \& Munger 2003; Martin 2001; Volden 1998), as well as on the Supreme Court (Caldeira et al. 1999). ${ }^{6}$

Existing formal models provide strong theoretical reasons for expecting decision makers to act in a sophisticated fashion when two conditions exist: (1) they possess adequate information about other relevant actors' preferences, and (2) they are clear about the agenda that will be discussed during the decisionmaking process (Krehbiel \& Rivers 1990). The reason is intuitive. Without adequate information, decision makers cannot accurately predict the preferences of those with whom they interact or the outcomes of subsequent votes. They therefore cannot calculate which course of action will yield the highest payoff. Further, without knowledge of

\footnotetext{
5 Sophisticated voting can be either sincere or insincere (see Austen-Smith 1987). A sophisticatedly sincere vote occurs when a decision maker, after considering likely outcomes at future stages of the game, realizes that choosing the most preferred option at one stage is the best way to achieve his or her goals at a later stage. A sophisticatedly insincere vote results when a decision maker votes against the most preferred alternative in order to reach outcomes at a later stage that are more preferred. Thus, we use the term sophisticated voting in this article as shorthand for sophisticatedly insincere voting.

6 There is also a rich, yet small, literature that focuses on sophisticated voting in legislatures beyond the United States (see, e.g., Huber 1996; Rasch 2000).
} 
the agenda that will be discussed, a decision maker cannot anticipate which proposals will be offered or determine what the decision tree looks like in advance. In other words, knowledge of the agenda allows political actors to know the alternatives from which they can choose and helps them determine how the decisions of other players in the game will affect their payoffs. Thus, without an agenda set prior to the decisionmaking process, sophisticated voting is extremely difficult.

The Supreme Court at least minimally satisfies the conditions necessary for justices to engage in sophisticated behavior (Caldeira et al. 1999). First, while the justices may not always possess complete and perfect information about their colleagues' preferences, the institutional setting of the Court provides them with ways of developing assessments about how the others are likely to behave. ${ }^{7}$ After all, justices encounter similar issues and work with a small number of individuals, often for long periods of time (Caldeira et al. 1999:551). Chief Justice Rehnquist explains that this helps the justices learn about their colleagues' preferences when he writes, "Each of us soon comes to know the general outlook of his eight colleagues. ..." (1987:294). Consequently, justices often have enough information to develop beliefs about their colleagues' preferences.

Second, the institutional structure of the Court's decisionmaking process serves to help set the agenda of each case before the justices come to conference to cast votes on the merits (see Sala \& Spriggs 2004). In fact, the norm that discourages justices from deciding issues sua sponte (Epstein et al. 1996) helps ensure that the Court will not entertain arguments not presented in written briefs or at oral argument. While litigants do not entirely determine the range of choices available to the Court, this norm provides the justices with information about the likely policy alternatives that will be considered in a case (Epstein \& Kobylka 1992; Wahlbeck 1997). Indeed, Johnson (2004) demonstrates that more than $80 \%$ of all arguments found in the Court's majority opinions derive from either the litigant or amicus briefs or from the oral arguments. This means that the justices have this information prior to the conference discussion in a case. ${ }^{8}$

7 While many formal models assert that complete and perfect information is necessary for sophisticated voting, Calvert and Fenno (1994) demonstrate that it is possible for actors to vote in a sophisticated fashion even without complete and perfect information. They find that, even with these information conditions, sophisticated voting occurred during the 1986 Senate debate over whether to allow full-time television coverage of Senate proceedings. However, the balance of evidence indicates that as an actor's uncertainty increases, the ability to cast a sophisticated vote decreases.

${ }^{8}$ As noted above, the justices might control the agenda somewhat, as there is some evidence of both issue suppression and issue creation on the Court (McGuire \& Palmer 1995, 1996). However, even McGuire and Palmer argue that these phenomena occur in a 
In addition, several institutional features provide the justices with information that allows them to anticipate subsequent stages of the judicial process (Caldeira et al. 1999). First, the Court's norms provide for a predictable set of decision stages before and after the conference vote in the form of open votes on certiorari, circulation of the first draft of the majority opinion, subsequent bargaining between other justices and the majority opinion author, and, finally, a vote by each justice. Second, the norm that governs opinion assignment helps the justices predict who the likely opinion assignor will be (Epstein \& Knight 1998). Thus, the nature of how issues are brought to the Court, combined with internal Court rules, provides the justices with a good sense for the range of alternatives available to them in a case.

\section{Passing During Supreme Court Conference Discussions}

Our general discussion of sophisticated voting raises the following question: Why would Supreme Court justices pass at conference? Indeed, if they have the ability to vote insincerely if a sincere vote will not help them reach their policy objectives, why would a justice decline to state a position? The answer, for us, is that when faced with uncertainty a justice may pass in order to enhance his or her information and to be able to cast a sophisticated vote, if necessary. ${ }^{9}$ As the above discussion indicates, in order to vote sophisticatedly, a justice must be able to predict which outcome will garner majority support. Without the ability to develop this expectation, a justice is unable to act sophisticatedly and thus may choose to pass, thereby waiting to cast a vote until all the other justices have voted. By passing, the justice can gain important information from the votes cast by other justices.

Despite the institutional features that may allow justices to anticipate their colleague's behavior, there is reason to believe that they do not always know how their colleagues want to act in specific

minority of cases. In addition, Calvert and Fenno (1994) argue that actors only need to have probabilistic knowledge of the agenda in order to engage in sophisticated behavior. As such, we are confident that the agenda for each case is set in such a way that justices can look down the game tree and know what their basic options will be.

9 This argument derives from Riker's (1986) theory of heresthetics. According to Riker, one way prospective losers can affect outcomes is by manipulating voting rules (Riker 1983, 1984, 1986, 1990; Nagel 1993; Epstein \& Shvetsova 2002). A resourceful "heresthetician" may, for example, use the rules of the institution to alter the voting procedure and, in the process, gain informational or other advantages over his or her opponents. Importantly, this tactic allows a decision maker to gather information and then, if necessary, cast a sophisticated vote at a later time. Heresthetics encompasses agenda control, strategic voting, and manipulation of dimensions to affect the final choice (Riker 1986). The latter two tactics generally require complete and perfect information, and thus we focus on the manipulation of voting rules in the form of passing (see Epstein \& Shvetsova 2002). 
cases. First, each case presents a unique set of facts and legal questions. Second, justices' preferences may change over time (Epstein et al. 1998). Third, justices' preferences vary across issue areas (Rohde \& Spaeth 1976). Fourth, most cases tap multiple issue dimensions, which creates ambiguity about which dimension is controlling (Maltzman \& Wahlbeck 1996). This variation in the justices' beliefs about their colleagues' views can undermine the level of information that is a necessary prerequisite to sophisticated voting. In such a setting, a strategic justice is less able to cast a sophisticated vote.

We do not expect all justices to have the same propensity to pass on their chance to vote at conference. ${ }^{10}$ Rather, we argue that the $\mathrm{CJ}$ has the greatest strategic incentive to pass because of the norm that allows him to assign the majority opinion when voting with the majority at conference. As existing accounts suggest (e.g., Epstein \& Knight 1998; Maltzman et al. 2000), this norm gives the chief a motivation, not shared by the associate justices, to vote with the majority at conference. ${ }^{11}$ Indeed, this norm gives the chief agenda-setting authority on the Court, which allows him to minimize the policy damage of an opinion that runs counter to his preferences by assigning the opinion to an ally or to himself.

In addition, the conference-voting norm on the Court stipulates that the order of voting is based on seniority, with the chief discussing and voting on a case first. This voting rule may put the chief at an informational disadvantage and make it difficult for him to take full advantage of the opinion-assignment norm. When faced with uncertainty based on this factor (or others), the chief is left with two options: either cast a sincere vote during conference, or pass and wait for the remaining justices to cast votes before voting himself.

Because casting a sincere vote may leave him out of the winning coalition, and therefore unable to assign the opinion, the chief may reserve his vote if he is unsure of which position will command a majority once all votes are cast. In essence, the chief passes in order to put himself in a position to vote with the majority and, in turn, to have greater leverage over the legal rule being crafted in the case. More specifically, the chief may pass in order to put him-

${ }^{10}$ Note that passing is different from abstaining. An abstention is based on the assumption that a later vote is not forthcoming, whereas, when passing, an actor leaves open the possibility of later casting a vote.

${ }^{11}$ We also argue that, because the SAJ has a realistic chance of assigning the majority opinion, he also has a strategic incentive to pass, though it is not as strong as the incentive for the chief. Note, however, that the SAJ only has this incentive if the CJ is not ideologically aligned with him because under this condition the SAJ will most likely disfavor the chief's position in the case. In the empirical analysis that follows, Justice William Douglas was the SAJ until his retirement, upon which time Justice William Brennan became the SAJ. Both of these justices were ideologically at odds with Chief Justice Burger. 
self into a position that will allow him to vote sophisticatedly. This leads to our general hypothesis:

Opinion Assignor Hypothesis: The chief justice is likely to pass at conference for strategic reasons, while associate justices are not likely to strategically pass.

\section{Uncertainty and the Strategic Incentive to Pass}

To recapitulate, we argue that the $\mathrm{CJ}$ passes when he lacks enough information about his colleagues' preferences and the case outcome to determine his best course of action. Despite the information that justices procure about their colleagues' behavior in past cases, as well as their behavior during the agenda-setting phase of the present case, their level of certainty about other justices' views may vary across cases. This lack of information gives the $\mathrm{CJ}$ an incentive to wait and see what his colleagues have to say about the case before casting a vote. As a result, we expect three indicators of uncertainty to influence when the chief will pass.

First, the CJ will base the decision to pass on his ability to predict which outcome is likely to receive majority support. If he anticipates that his preferred outcome is likely to prevail in the end, he has no need to pass and will therefore cast a substantively sincere vote at conference. And the chief is unlikely to pass when he anticipates that his position will not be adopted by the majority. Again, under this condition the chief has enough information to decide what to do, and he will therefore respond with a substantive vote. However, if the chief is unsure of the likely position to be adopted by the majority, he may pass to preserve the possibility of casting a sophisticated vote.

If justices are ideologically close to their colleagues, they know that the legal outcome of the case is likely to resemble their preferred outcome, especially as the ideological distance between them and the Court's median justice becomes smaller. ${ }^{12}$ We expect a CJ in this position to cast a vote at conference and not to pass, because he believes that his preferred position is likely to be the majority's view. When the chief is ideologically distant from the median justice on the Court, he will predict that his position will most likely not be the majority view. Since the chief has a reasonable level of information about the likely case outcome in this situation, we again predict he will cast a substantive vote and not pass. However, when the chief is neither too close nor too far from the median justice, he will be less sure of which outcome will prevail and thus

${ }^{12}$ We use the Court median because it serves as a reasonable proxy for the likely case outcome (see Spriggs \& Hansford 2001). 
pass to gain information from his colleagues' votes in the case. In short, we expect the chief to be more likely to pass when he is less certain about the likely case outcome, which he can infer from his ideological distance from the median justice on the Court. This leads us to predict that the chief's ideological distance from the median justice acts in a curvilinear fashion:

Distance from Court Median Hypothesis: The chief will be more likely to pass when he is less certain about the outcome of the case and less likely to pass when he has greater information.

Second, given the rule of four, whereby a case is placed on the Court's docket if four justices vote to grant certiorari, a certiorari coalition of only four justices indicates greater uncertainty about the final outcome. More specifically, because of the instability of a minimum-winning coalition (Hoekstra \& Johnson 2003), the level of uncertainty is greater when a coalition is smaller, and justices have more leverage over the outcome of a case (Riker 1962; Murphy 1964; Maltzman et al. 2000). Thus, when the certiorari coalition is minimum-winning, the CJ may be more willing to wait to hear what his colleagues have to say on the merits before voting. For this reason, we hypothesize that:

Case Outcome Uncertainty Hypothesis: The chief is more likely to pass when the coalition granting certiorari in a case is minimum-winning.

Third, the chief can predict the likely case outcome based on how his colleagues have decided similar cases in the past (Rehnquist 1987; Murphy 1964; Baum 2001). Indeed, justices' information about the preferences held by their colleagues is largely acquired through interaction in earlier cases, and scholars have demonstrated that uncertainty about case outcomes is heightened when justices' views in prior cases dealing with similar issues are not clear (Maltzman et al. 2000). Yet while justices have numerous opportunities to observe the behavior of their colleagues in some issue areas (e.g., civil liberties), these opportunities to learn the views of others may be less plentiful in other issue areas. In other words, when the other eight justices have participated in fewer cases within an issue area, the outcome of the present case is less certain to the CJ because he has less information about how his colleagues have acted in the past. This leads us to hypothesize:

Preference Uncertainty Hypothesis: The chief is more likely to pass when the number of past cases decided by other justices on the Court in an issue area is smaller. 
We also expect the chief to respond to the relative importance of a case. Given the likely impact of legally and politically important cases, he is more likely to want to assign the majority opinion, or to actually write the opinion, in these cases. ${ }^{13}$ Past research, for example, indicates that the chief is more likely to assign opinions to ideological allies in salient cases (Maltzman et al. 2000). In addition, the Court is more likely to hear reargument (Hoekstra \& Johnson 2003), and justices more frequently bargain with one another before joining an opinion (Spriggs et al. 1999), in highly salient cases. A memo from Justice Powell to Chief Justice Burger illustrates this idea: "At the conference yesterday, I reserved my vote to enable me to give further thought to this important and difficult case" (Powell 1978:n.p.). In short, the stakes are higher in salient cases, and thus the conference vote becomes even more critical. Thus, we hypothesize:

Case Salience Hypothesis: The chief is more likely to pass in cases of greater salience.

\section{Nonstrategic Explanations for Passing}

We also recognize that justices may pass at conference for reasons unrelated to strategic voting. Some justices may pass sincerely without any intention of casting a sophisticated vote or of manipulating the outcome. Chief among the reasons for a sincere pass is that in some cases justices lack information about, or are unsure of, their views of the issues under discussion in a case. This scenario is most likely to occur in complex cases where justices may be undecided about their position. This relationship is evidenced in a memo written by Justice Sandra Day O'Connor to Chief Justice Burger in Spencer v. South Carolina Tax Commission (1985), where O'Connor wrote,

"passed" at the Conference on this case and have continued to read cases and other materials on point. My vote, which remains tentative, is in accord with yours - to reverse. Although I think the $\$ 1988$ attorneys' fees provision is enforceable in state court as part and parcel of $\$ 1983$ actions, I do not believe injunctive relief need be given or that plaintiffs can bypass state administrative remedies. Of course, these last two matters are not raised in

${ }^{13}$ We want to be clear that our argument is not that salience directly taps interdependency of choice. Rather, we suggest that salience serves to give justices a greater incentive to act strategically. Salience is therefore a policy-based motivation related to the chief's desire to influence policy in important cases. We include it under the "strategic" heading because we do not expect salience to influence associate justices, who lack this policy-based motivation. 
this case, but they will be "lurking" in the wings (O'Connor 1985:n.p.).

Consistent with this expectation, Maltzman and Wahlbeck (1996) show that justices are more likely to change their votes after the conference in complex cases. This leads to the following hypothesis:

Case Complexity Hypothesis: All justices are more likely to pass in cases of greater complexity. ${ }^{14}$

Finally, past research often suggests that it takes time for "freshman" Supreme Court justices (i.e., those new to the bench) to acclimate to their job (e.g., Brenner \& Hagle 1996; Howard 1968). Freshmen are often said to be more likely to follow rather than lead, to exhibit less stable voting patterns, and to be less familiar with the issues being decided by the Court. As a result, one might expect that freshmen would be more likely to pass at conference.

Freshman Justice Hypothesis: Freshman justices will be more likely to pass than their more senior colleagues.

\section{Data and Methods}

We based our analysis on a random sample of 1,043 cases decided between the 1971 and 1985 October terms. ${ }^{15}$ Specifically, we merged two random samples; in one sample, we selected all cases from seven random terms $(1971,1974,1976,1979,1980,1984$, and 1985), and in the other we randomly sampled 359 cases from the remaining terms. ${ }^{16}$ Based on these data, we could test our

14 Although we characterize case complexity as a nonstrategic basis for passing, we recognize the possibility that more complex cases may lead to strategic passes as well. After all, justices may be less certain about how colleagues will vote in complex cases, leading them to reserve their vote. If these strategic considerations were the reason that motivated passes in complex cases, given the CJ's unique incentive to pass, we would not expect this variable to have an effect on associate justices. Analysis of the data reveals, however, that case complexity has a greater effect on associate justice passing than on CJ passing. This result leads us to suspect that case complexity is a source of sincere passes, as we discuss above.

15 We took our sample from Spaeth (2001a), with the universe of cases defined as all full opinion, orally argued per curiam, and judgments of the Court. The unit of analysis is the docket number.

16 This sampling procedure results from the fact that this article has gone through several iterations. For the first iteration, we drew a random sample of cases from the time frame of our analysis. The results were good, and interesting, but we wanted additional data to make our analysis more generalizable. Thus, we returned to the Powell archives a year later with the intention of coding every case from every term between 1971 and 1986. Given our time constraints at the archives, however, this was not an attainable goal. Thus, we chose a random sample of terms and appended all the cases from these terms to our original sample. We have no reason to weight the data or estimates since we have not oversampled based on any particular characteristics of the data. 
argument that the $\mathrm{CJ}$ (Warren Burger), but not the remaining associates, passed for strategic reasons. We then extended this analysis in two ways. First, we applied our argument to one other justice who may be in a position to assign the majority opinion in a case: the SAJ. Second, we conducted a preliminary replication of our results for Chief Justice Burger by analyzing the conference votes in all cases decided during the 1986 term ( $n=153$ cases), which was Justice Rehnquist's first term as chief. In the CJ models, we compared the chief to all of the associate justices except the SAJ because the SAJ may also pass for strategic reasons. Note, however, that our results did not appreciably change if we include the SAJ in the analysis. Finally, for the SAJ model we excluded the CJ from consideration, and therefore only compared the SAJ to all other associates.

We analyzed the 1971-1986 terms because we drew our data from the Supreme Court papers of Justice Powell, whose tenure on the Court was limited to these terms. ${ }^{17}$ Powell's conference notes provide uniquely detailed accounts of the conference discussion. While some justices, such as William Brennan, recorded only the final conference position of each justice on their docket sheets, Powell's notes indicate changes in position during the course of the conference discussion. Thus, Powell's records have evidence of passes when a justice ultimately cast a substantive vote at conference. ${ }^{18}$ Moreover, Powell's conference record is highly reliable, as the Maltzman et al. analysis demonstrates (2000:164).

A number of phrases in Powell's records indicate that a justice passed at conference: pass, not at rest, reserve judgment, will wait to hear what others say, and will wait until end of discussion. Using these phrases, our dependent variable captured whether a justice passes during the course of the conference discussion. We coded it as one if a justice passed and zero otherwise. In the sample of cases from 1971 to 1986 , there were 246 passes in 10,578 votes $(2.3$ percent). Table 1 presents the frequency with which each justice passed during these terms.

Normally, logistic regression is an appropriate modeling choice for a dichotomous dependent variable, but this technique underestimates the probability of a rare event occurring (King \& Zeng $2001 \mathrm{a}, 2001 \mathrm{~b})$. Specifically, the estimated coefficients in rare events are biased downward, which affects the constant term and the re-

${ }^{17}$ Lewis Powell became a Supreme Court justice on January 7, 1972, which was during the 1971 term. Thus, we include this term and analyze cases in which Powell participated.

${ }^{18}$ When we compared our data from Powell's conference notes with Spaeth's (2001b) final merits vote at conference, we found that 80 of the passes recorded in Powell's notes are coded as substantive votes or as tentative, but substantive, votes in Spaeth's data set. 
Table 1. The Frequency with Which Justices Pass at Conference in a Random Sample of Cases from 1971 to 1986 Terms

\begin{tabular}{lrc}
\hline Justice & Number of Passes & $\begin{array}{c}\text { \% of Conference Votes } \\
\text { in Which Justice Passed }\end{array}$ \\
\hline Warren Burger & 122 & $11.8 \%$ \\
William Douglas & 9 & $4.8 \%$ \\
William Brennan & 18 & $1.5 \%$ \\
Potter Stewart & 30 & $4.2 \%$ \\
Byron White & 11 & $0.9 \%$ \\
Thurgood Marshall & 6 & $0.5 \%$ \\
Harry Blackmun & 6 & $0.5 \%$ \\
Lewis Powell & 13 & $1.1 \%$ \\
William Rehnquist (as associate justice) & 5 & $0.5 \%$ \\
William Rehnquist (as chief justice) & 8 & $5.2 \%$ \\
John Paul Stevens & 11 & $1.2 \%$ \\
Sandra Day O'Connor & 5 & $1.0 \%$ \\
Antonin Scalia & 2 & $1.3 \%$
\end{tabular}

Source: Conference Notes of Justice Lewis F. Powell, Washington \& Lee University, Lexington, VA.

maining coefficients. King and Zeng (2001a, 2001b) developed a correction for this problem that lowers the mean square error of a model, which they call rare event logistic regression. ${ }^{19}$ Because our dependent variable was an infrequent event, we employed this modeling strategy in conjunction with Stata 8.2 (Tomz et al. 1999).

\section{Independent Variables}

\section{Distance from Court Median and Distance from Court Median-Squared}

We argue that the chief will be more likely to pass when he is less certain about the outcome in a case and less likely to pass when he either expects to win or lose on the merits. To measure this concept, we examined each justice's ideological compatibility with the median justice on the Court. As a measure of ideology, we used the percentage of the time the justice has voted in a liberal direction in the Spaeth value area of a case in terms prior to the one in which the case was decided (Spaeth 2001a). ${ }^{20}$ We then included

19 To control for the possibility of correlated errors within a single justice's votes over time, we used robust standard errors, clustering on each justice.

${ }^{20}$ Spaeth assigns cases to 12 different substantive "value" (i.e., issue) areas, such as the First Amendment, privacy, civil rights, and criminal process. If a case raised more than one value, we took the mean of the justice's ideology in the two value areas.

We lack a measure of ideology for a justice's first term on the Court since our variable is based on prior voting behavior. We therefore had to determine a means of assessing these justices' ideology. To do so, we regressed the percentage of the time each justice voted liberally in each Spaeth value area during his or her first full term on the Court on the Segal/Cover score for that justice (Segal et al. 1995). Since a justice's ideology also reflects the nominating president's preferences and the confirming Senate's policy views, we also 
two variables in our empirical model. Distance From Court Median represented the absolute value of the ideological distance between each justice and the ideology of the median justice on the Court, and Distance From Court Median-Squared was the squared value of the former variable.

By using this quadratic formulation, we could test for the curvilinear effect predicted by our hypothesis. In particular, we expected a positive coefficient on Distance From Court Median, meaning the chief is more likely to pass as he gets further from the median justice (or, put otherwise, less likely to pass when he is closer to the median). We predicted a negative coefficient for Distance From Court Median-Squared, which would indicate that the chief becomes less likely to pass when he is quite far from the median (because he expects to lose the case). Distance From Court Median ranged from 0 to 0.692 , with a mean of $0.115 .^{21}$

\section{Preference Uncertainty}

To measure the justices' uncertainty regarding their colleagues' preferences in a case, we examined the mean number of cases in which the other sitting justices participated prior to the present case for each issue area. In other words, for each justice we calculated the mean number of cases in which the other justices previously participated in each issue area. The mean of this variable was 256.4, and it ranged between 6.2 and 489.4.

\section{Outcome Uncertainty}

Using Powell's docket sheets, we measured a justice's uncertainty over the outcome of a case by determining whether the coalition that placed the case on the Court's agenda was the minimum size necessary - four votes out of nine justices. Of the 1,043 cases in our sample decided during the Burger Court, 292 were placed on the agenda by a minimum-winning certiorari coalition.

included the president's Nominate score and the median Senator's Nominate score on the right-hand side of the model. Finally, because the Segal/Cover measure is more predictive in some issue areas than others (see Epstein \& Mershon 1996), we interacted it with a series of dummy variables that indicated the observation's value area. We obtained these data from Spaeth (2001a) and included data from the first full term of all justices from Earl Warren to Stephen Breyer. Each justice had 12 observations, which corresponded with his or her voting behavior in each of the 12 value areas. After running the regression, we obtained the predicted probability of voting liberally for each justice. We then inserted these predicted probabilities for each Spaeth value area into the main data set for the "new" justices during our time frame (following are the terms when each justice joined the Court): Stevens (1975), O'Connor (1981), and Scalia (1986).

${ }^{21}$ Unless otherwise stated, the summary statistics for the independent variables were for the Chief Justice Burger model. 


\section{Case Salience}

To measure the salience of a case, we used the level of amicus curiae participation in a case on the merits (Gibson 1997). Given that amicus participation has dramatically increased over the terms included in this sample, we calculated term-specific $z$-scores to determine whether a case had more amicus filings than the average case heard during a term. This variable had a mean and standard deviation of 1.7 and 3.6, respectively.

\section{Associate Justice}

We created a dummy variable that equaled one if a justice was an associate justice. We then interacted this variable with the other strategic voting variables in our analysis, resulting in the following variables: Distance From Court Median * AJ, Distance From Court Median-Squared *AJ, Preference Uncertainty * AJ, Case Outcome Uncertainty* AJ, and Case Salience * AJ.

\section{Case Complexity}

To measure case complexity, we conducted a factor analysis of all cases decided by the Supreme Court between the 1971 and 1986 terms. Using Spaeth (2001a), we counted the number of legal issues raised in the case, the number of legal provisions at issue, and the number of opinions written by justices. The factor analysis resulted in a single factor with an eigenvalue greater than one. We assigned the factor score that resulted from this analysis for each case. The average Case Complexity measure in our sample was 0.16 , with a standard deviation of 0.89 .

\section{Freshman Justice}

We coded any justice who had served fewer than two full years on the Court when a case was orally argued as a freshman justice (starting from the date on which the justice took the oath of office). Freshman justices cast just over $5 \%$ of the votes in our analysis.

\section{Results}

We argue that the CJ's decision to pass at conference results, in part, from his desire to influence the final outcome on the merits. Because the opinion assignment norm grants the chief the power to assign when in the majority, he has an incentive to join this coalition in order to take advantage of agenda-setting effects. But when lacking information about the other justices' views, he may be uncertain of which position will ultimately gain majority support. 
Table 2. Rare Events Logit Model of the Chief Justice's and Senior Associate Justices' Propensity to Pass at Conference on the U.S. Supreme Court, 1971-1985 Terms

\begin{tabular}{lcc}
\hline & $\begin{array}{c}\text { Chief Justice }(C J) \\
\text { Coefficient (Robust } \\
\text { Standard Error) }\end{array}$ & $\begin{array}{c}\text { Senior Associate Justice (SAJ) } \\
\text { Coefficient (Robust } \\
\text { Standard Error) }\end{array}$ \\
\hline Independent Variable & $10.401(0.112)^{*}$ & $-3.805(0.420)$ \\
Distance From Court Median & $-17.600(0.395)^{*}$ & $6.902(2.858)$ \\
Distance From Court Median-Squared & $-0.0008(0.0000)^{*}$ & $-0.006(0.001)^{*}$ \\
Preference Uncertainty & $0.060(0.001)^{*}$ & $0.411(0.037)^{*}$ \\
Case Outcome Uncertainty & $0.028(0.003)^{*}$ & $-0.047(0.036)$ \\
Case Salience & & \\
Strategic Variables $($ AJ) & $-1.340(0.630)^{*}$ & $-2.025(0.672)^{*}$ \\
Associate Justice (AJ) & $-8.292(4.444)^{*}$ & $5.878(4.547)$ \\
Distance From Court Median * AJ & $3.533(12.124)$ & $-20.867(13.037)$ \\
Distance From Court Median-Squared * AJ & $-0.0001(0.0001)$ & $0.005(0.001)^{*}$ \\
Preference Uncertainty * AJ & $0.125(0.232)$ & $-0.222(0.240)$ \\
Case Outcome Uncertainty * AJ & $0.002(0.021)$ & $0.074(0.047)$ \\
Salience * AJ & & \\
Nonstrategic Variables & $0.214(0.097)^{*}$ & $0.292(0.095)^{*}$ \\
Case Complexity & $0.605(0.452)$ & $0.612(0.454)$ \\
Freshman Justice & $-2.903(0.029)^{*}$ & $-2.241(0.121)^{*}$ \\
Constant & 8,242 & 8,171 \\
Number of Observations & & \\
\hline
\end{tabular}

Note: $* p \leq 0.05$ (one-tailed test). The first five coefficients in each model show the effect of each variable for the CJ (column 2) or the SAJ (column 3) only. The coefficients for the interaction terms between the associate justice variable and each of the strategic variables show the difference in their effect on the associate justices (except for the SAJ) and the CJ. The coefficients for the nonstrategic variables show the effect for all justices.

In such a context, the chief can pass to gain additional information from the other justices' votes. Based on the data analysis reported in Table 2, we first discuss the results for Chief Justice Burger (column 2), and then we apply our argument to the SAJ in each case (column 3). From there we examine how the remaining associate justices differ from the CJ and SAJ (Table 3). Finally, we

Table 3. Testing the Hypothesis of No Influence on Associate Justices' Decision to Pass

\begin{tabular}{lccc}
\hline & $\begin{array}{c}\text { Chief Justice Model } \\
(1971-1985 \text { OT) } \\
\text { Coefficient (Robust } \\
\text { Standard Error) }\end{array}$ & $\begin{array}{c}\text { Chief Justice Model } \\
\text { (1986 OT) } \\
\text { Coefficient (Robust } \\
\text { Standard Error) }\end{array}$ & $\begin{array}{c}\text { Senior Associate } \\
\text { Justice Model } \\
\text { Coefficient (Robust } \\
\text { Standard Error) }\end{array}$ \\
\hline Independent Variable & $2.109(4.460)^{*}$ & $-30.179(23.405)^{*}$ & $2.073(4.457)^{*}$ \\
\hline $\begin{array}{l}\text { Distance From Court } \\
\text { Median }\end{array}$ & $-14.067(12.154)$ & $148.411(50.676)^{*}$ & $-13.964(12.125)$ \\
$\begin{array}{l}\text { Distance From Court } \\
\text { Median-Squared }\end{array}$ & $-0.001(0.001)$ & $0.002(0.004)^{*}$ & $-0.001(0.001)$ \\
$\begin{array}{l}\text { Preference Uncertainty } \\
\text { Case Outcome Uncertainty }\end{array}$ & $0.185(0.232)^{*}$ & $-0.129(1.283)^{*}$ & $0.189(0.228)^{*}$ \\
Case Salience & $0.030(0.020)$ & $0.108(0.083)$ & $0.027(0.020)$ \\
\hline
\end{tabular}

Note: ${ }^{*} p \geq 0.20$ (one-tailed test). The test of significance in this table is based on the null hypothesis that each of these variables has an influence on associate justices. We derived these coefficients and standard errors from the results reported in Table 2 (see footnotes 25,27$)$. 
Table 4. Rare Events Logit Model of the Chief Justice's Propensity to Pass at Conference on the U.S. Supreme Court, 1986 Term

\begin{tabular}{lc}
\hline Independent Variable & $\begin{array}{c}\text { Chief Justice Coefficient } \\
\text { (Robust Standard Error) }\end{array}$ \\
\hline Strategic Variables $(\boldsymbol{C J})$ & $50.263(26.231)^{*}$ \\
Distance From Court Median & $-127.822(61.459)^{*}$ \\
Distance From Court Median-Squared & $0.0004(0.001)$ \\
Preference Uncertainty & $-0.372(0.032)$ \\
Case Outcome Uncertainty & $0.086(0.017)^{*}$ \\
Case Salience & \\
Strategic Variables $(A J)$ & $1.907(3.399)$ \\
Associate Justice (AJ) & $-71.540(40.277)^{*}$ \\
Distance From Court Median * AJ & $212.175(88.165)^{*}$ \\
Distance From Court Median-Squared * AJ & $0.001(0.004)$ \\
Preference Uncertainty * AJ & $0.295(1.289)$ \\
Case Outcome Uncertainty * AJ & $0.014(0.078)$ \\
Salience * AJ & \\
Nonstrategic Variables & $0.377(0.231)$ \\
Case Complexity & $1.911(1.159)^{*}$ \\
Freshman Justice & $-7.326(2.959)$ \\
Constant & 1,209 \\
Number of Observations & \\
\hline
\end{tabular}

Note: ${ }^{*} p \leq 0.05$ (one-tailed test). The first five coefficients in the model show the effect of each variable for Chief Justice Rehnquist only. The coefficients for the interaction terms between the associate justice variable and each of the strategic variables show the difference in their effect on the associate justices (except for the SAJ) and the CJ. The coefficients for the nonstrategic variables show the effect for all justices.

replicate our analysis with data for Chief Justice Rehnquist (Table 4).

\section{Chief Justice Burger}

The coefficients for Distance From Court Median and Distance From Court Median-Squared, taken together, provide some evidence that Chief Justice Burger tended to pass when he was more uncertain about whether he would be in the majority coalition. More specifically, when Chief Justice Burger was confident he would be in the winning coalition (because he was ideologically aligned with the median justice), he passed in only $4.6 \%$ of votes. ${ }^{22}$ As expected, this probability increased when Burger was neither too close to nor too far removed from the median. Indeed, in this setting the chief was less certain he would win the case and therefore, as expected, his rate of passing increased to $11.3 \%$. While the negative and statistically significant coefficient on Distance From Court MedianSquared comported with our expectation statistically, it was not fully

22 To calculate all of the predicted probabilities, we held each variable constant at its mean value for the CJ (or, for a categorical variable, its modal value). So that our predicted probabilities would pertain to the CJ, we set Associate Justice to zero and set each of the interaction terms to zero. We set Distance From Court Median at 0 for a chief aligned with the median and at its mean when he was somewhat distant. 
supportive of Burger being less likely to pass when he expected to be in the losing coalition. The reason is that Burger only became significantly less likely to pass after the value of this variable went beyond the observed range for him. Specifically, the model predicted that the effect of Distance From Court Median switched direction at the value of 0.295 (the maximum value for Burger is 0.311, while it is 0.695 for the remaining justices), and his probability of passing did not dip below $10 \%$ until this variable reached 0.500 . Thus, while this result partially supported our argument, we cannot definitively conclude that, for Burger, this factor worked as we anticipated it would.

The coefficients for the other two measures of uncertainty provide stronger evidence for our argument. The coefficient for Preference Uncertainty indicated that the CJ was more likely to pass when he had less-clear expectations about the preferences of his colleagues. Substantively speaking, the probability that Chief Justice Burger would pass increased from $10.3 \%$ to $12.5 \%$ if the other justices had decided fewer, rather than more, past cases in the same issue area as the present case. This represents about a $21 \%$ change in the probability of the chief's passing at conference. The coefficient for Case Outcome Uncertainty indicated that when the chief had greater certainty about the outcome of the case (because the certiorari-granting coalition was not minimum-winning) he passed $11.3 \%$ of the time, while this percentage increased to $12.0 \%$ when the certiorari coalition was minimum-winning. In addition, our data provide evidence that the $\mathrm{CJ}$ is more likely to pass in salient cases. Our model predicted that the chief had a $10.6 \%$ chance of passing in less-salient cases, while this figure increased to $12.4 \%$ in more salient cases. ${ }^{23}$

\section{SAJs}

While we argue that associate justices do not pass for strategic reasons because they rarely assign the majority opinion, one associate has a nontrivial chance of assigning: the most senior associate justice in a case. ${ }^{24}$ Recall that the opinion-assignment norm indicates that if the chief votes with the minority, the most senior member of the majority will assign the opinion. The reason we expected the SAJ to pass for strategic reasons is that, if the chief

23 To calculate the probabilities for Case Salience and Preference Uncertainty, we set case salience at one standard deviation below and above its mean.

24 Again, we point out that our argument only applies to the SAJ when he is ideologically at odds with the CJ, as is the case for the time period we study; Brennan and Douglas (the SAJs over this time period) were ideologically removed from Chief Justice Burger (data available from the authors upon request). 
votes with the minority, the $\mathrm{SAJ}$ is the associate justice with the greatest ex ante expectation of being able to assign the opinion. For example, during the Burger Court era the SAJ assigned 11.2\% of the majority opinions. Combined, the remaining associate justices assigned in only $2.9 \%$ of the cases. Column 3 in Table 2 presents the results of our analysis comparing the SAJ to all other associates.

The results for the SAJ were somewhat similar to those for the CJ. ${ }^{25}$ The one notable difference was Distance From Court Median and Distance From Court Median Squared; while these variables had an influence on the chief, they did not influence the SAJ's decision to pass in the way we hypothesized. ${ }^{26}$ The SAJ did, however, respond to the other elements of uncertainty in our model. When considering the substantive effects, keep in mind that our model predicted that the CJ passes $11.4 \%$ of the time, while it predicted that the SAJ only does so in $1.3 \%$ of all conference votes. The coefficient for Preference Uncertainty indicated that when the SAJ had less-clear expectations about his colleagues' preferences, the probability of passing increased. For example, the SAJ passed in $0.6 \%$ of votes when he had greater knowledge of his colleagues' preferences and passed in $2.9 \%$ of cases when he was less clear about their preferences in a case. ${ }^{27}$ This effect represents a substantial $383 \%$ change in the probability of the SAJ passing at conference. Case Outcome Uncertainty also demonstrated a sizable effect, as the SAJ's tendency to pass increased from $1.3 \%$ when the certiorari coalition was not minimum-winning compared to $2.0 \%$ when it was (for a $53.8 \%$ change in the likelihood of passing).

\section{Associate Justices}

We now turn to a test of our expectation that the associate justices would not pass for strategic reasons. In Table 3 we present the effect of each of the strategic variables on the associate justices'

25 The number of observations was different in the SAJ and CJ models because we excluded the CJ in the latter, whereas in the former we excluded the SAJ. The results in Table 2 did not change appreciably if we included a control variable for the number of justices voting in a case who passed earlier in the voting order. This variable indicates that all justices are more likely to pass when a greater number of justices voting before them in a case have passed.

26 Tests for these coefficients exceeded the conventional values for statistical significance, but the signs were in the wrong direction. Therefore we do not indicate in Table 2 that they are statistically significant; contrary to our theory, these results would seem to indicate that the SAJ may be less likely to pass when he is near the median justice rather than far from the median.

27 For the following predicted probabilities, we set the variable of interest at one standard deviation above and below its mean for the SAJs, and controlled for other variables at their mean or modal values. 
decisions to pass. ${ }^{28}$ We calculated these effects for associate justices by adding each non-interacted coefficient (e.g., Distance From Court Median) to its interaction term (e.g., Distance From Court Median* $A J)$, and then determined the standard errors based on the formula in Friedrich (1982:810). ${ }^{29}$ As argued above, we expected each of the variables representing strategic decisionmaking to be statistically insignificant for the associate justices. Again, the reason is that they will not expect, even if they have insincerely voted with the majority, to assign the opinion. ${ }^{30}$ As Table 3 indicates, the associate justices' decisions to pass were not influenced by Distance From Court Median or Distance From Court Median-Squared. ${ }^{31}$ This result indicates that associate justices do not pass in an attempt to manipulate an anticipated adverse ruling by the Court, unlike the CJ. Our findings, however, do not refute the possibility that associate justices pass in response to the other two measures of uncertainty or in salient cases.

Like the comparison of associate justices with the CJ, the SAJ is somewhat distinct from his more junior colleagues. The effect of Preference Uncertainty (as seen in column 3 of Table 2) for the SAJ was significantly different from that of the associate justices. As we expected, we can conclude that Distance From Court Median and Case Outcome Uncertainty do not influence the associate justices (as seen in column 4 of Table 3).

${ }^{28}$ The columns in Table 3 represent the effects for the associate justices in each model. Column 2 focuses on the CJ model from 1971 to 1985, column 3 focuses on the CJ model from 1986, and column 4 focuses on the SAJ model.

29 When interacting a dichotomous variable, such as Associate Justice, with a principal variable (e.g., Distance From Court Median), the interaction term only measures the difference in the effect for the principal variable between the two populations represented by the dichotomous variable. While the non-interacted principal variable reflects the effect of this variable for the $\mathrm{CJ}$, the interaction term does not reveal whether the principal variable is significant for the second population (i.e., associate justices). To make that determination, one must calculate the effect and the standard error of this effect. As Friedrich notes, "By calculating the conditional standard error associated with each conditional slope, the researcher can test whether or not an independent variable has a statistically significant effect on the dependent variable at any specified level of another independent variable" (1982:832).

30 We conjecture that associate justices not in a position to assign the majority opinion will generally not vote insincerely at conference, and thus they have no strategic incentive to pass. The reason is that voting insincerely is rarely going to move Court policy closer to a justice's ideal point since, in most cases, a justice who is ideologically distant from the opinion assignor or opinion author is unlikely to influence the formation of the majority opinion (see Maltzman et al. 2000). Thus, only a justice likely to be able to assign the majority opinion would be motivated to vote insincerely.

31 One must minimize Type II errors when making a hypothesis of no effect, and Blalock (1979:161) advocates using an alpha in the 0.10 to 0.30 range. We rejected the null hypothesis if the alpha was $\geq 0.20$. 


\section{Nonstrategic Reasons for Passing}

Finally, we controlled for two other factors. First, justices may pass due to indecision in complex cases. The coefficient for Case Complexity was significant, indicating that all justices are substantially more likely to pass when confronting more difficult legal issues. For example, the likelihood of Chief Justice Burger passing increased from 9.6 to $13.4 \%$ when voting in cases having more, rather than less, complexity. ${ }^{32}$ In addition, our model predicted that associate justices pass $1.1 \%$ of the time in less-complex cases and $1.6 \%$ of the time in more complex cases. The variable for freshman justices, while positive, was not statistically distinguishable from zero.

\section{Chief Justice Rehnquist}

We also conducted a preliminary test of the generalizability of the results we obtained for Chief Justice Burger by analyzing conference votes during the 1986 term of the Court. Consistent with our expectation, Justice Rehnquist's propensity to pass increased a dramatic $940 \%$ from his time as an associate $(0.5 \%)$ to his first term as chief $(5.2 \%)$. Our argument is that this increase was due to the opinion assignment norm. Our data, moreover, indicate that an alternative conjecture - that his increased propensity to pass resulted from a general effect in which justices who voted earlier in the voting order passed due to informational constraints - was inaccurate. ${ }^{33}$

As seen in Table 4, one of the three factors tapping strategic decisionmaking influenced Chief Justice Rehnquist's decision to pass. Specifically, Rehnquist was more likely to pass when he was uncertain about whether he would be in the majority coalition. When Rehnquist was quite confident that he would be in the winning coalition (because he was ideologically aligned with the median on the Court), he passed only $1.2 \%$ of the time. Likewise, when he expected to be on the losing side (because he was ide-

32 To calculate these numbers, we set Associate Justice (and its interactions) to zero, the other continuous variables to their means, and Case Outcome Uncertainty to its mode. We then changed Case Complexity from one standard deviation above to one below its mean value. For the associate justice effects, we set Associate Justice to one and set the interaction terms to their appropriate values.

33 Specifically, we ran our model for Chief Justice Burger and our model for the SAJ with a set of dummy variables representing each of the "seats" on the Court, dropping one to serve as a baseline. We then ran each model iteratively for each seat, allowing each seat to serve as the reference category. We found that the chief and SAJ are more likely to pass than other associate justices. There was little to no difference in the probability of passing when comparing the other associate justices to justices voting deeper in the voting queue (although Justice Stewart, when he was the third most senior member of the Court, passed more often than his more junior colleagues). 
ologically distant from the median justice on the Court), he only passed $2.8 \%$ of the time. However, when he was less certain about whether he would be in the majority (because he was neither too far from nor too close to the median), his rate of passing increased to $11.7 \% .^{34}$ Note that these effects, unlike for Burger, were well within the range of the data for Chief Justice Rehnquist. However, the coefficients for Preference Uncertainty and Case Outcome Uncertainty indicated that they did not influence his behavior. In addition, in Table 3 (column 2) we test our hypothesis that the strategic voting variables will not influence the associate justices. As evidenced, we can conclude that each of the strategic voting variables (except for Case Salience) has no influence on their decisions to pass.

We therefore have two reasons to conclude, at least tentatively, that the strategic behavior exhibited by Justice Burger was not isolated to him. First, our results for the SAJs (Justices Douglas and Brennan) resembled the results for Chief Justice Burger. Second, while recognizing that our replication data for Chief Justice Rehnquist only cover his first term as chief, they show that he too was influenced by uncertainty. While the precise measures of uncertainty that appeared to affect Chief Justices Burger and Rehnquist do differ, the chief justices nevertheless both responded to uncertainty by becoming more willing to pass. Consequently, we have data, going beyond Burger, to demonstrate that SAJs and the chief pass at conference for strategic reasons.

\section{The Impact of Passing at Conference}

As the foregoing pages reveal, our expectations about which justices are likely to pass have largely been sustained. However, the analysis does not address the impact of passing during the conference discussion. Our theory suggests that passing occurs because the conditions that enable the chief to cast a sophisticated vote are absent. This means that, when the chief passes for strategic reasons, he is in a less than optimal situation. As a result, we do not expect the chief to always vote sophisticatedly after he passes, but only to do so under conditions that will allow him to set the agenda.

The question, then, is, when might we see the chief follow up a pass with a sophisticated vote to control the agenda? This outcome would be evident, for instance, in the assignment patterns of cases in which the chief initially passes at conference and later expresses

34 To calculate these effects, we set independent variables at their mean or modal values for Chief Justice Rehnquist and manipulated the variable of interest from its minimum value of 0.030 when Rehnquist was ideologically aligned with the median, its maximum value of 0.312 when he was ideologically distant, to its mean value of 0.174 for the in-between situation. 
a view after other justices have spoken. Our expectation was that when the chief takes this tack, his vote will often be sophisticated so that he can ultimately assign the opinion. The results were compelling. Of the 56 cases in which the chief passed and then voted at conference, he assigned the opinion in 52 of them (92.9\%). This percentage was significantly different from the chief's assignment rate in cases when he did not pass $(84.8 \%, p=0.05)$, and from cases in which he passed but did not state a position at conference $(69.6 \%, p=0.0005){ }^{35}$

Sophisticated voting would more explicitly manifest itself in the ideological direction of the chief's final vote on the merits. If Chief Justice Burger voted in a sophisticated manner, then we expected that he would be more likely to vote liberally when he passed and assigned the majority opinion than when he did not pass and assigned. The intuition was that he would join a more liberal coalition to minimize the damage from a liberal opinion. Again, the results were strong. The chief voted liberally $33.1 \%$ of the time when he did not pass and then assigned the majority opinion. This percentage increased to $52.1 \%$ when he passed and then assigned. This difference was statistically significant at $p=0.0001$. From these results, we can infer that Chief Justice Burger used his ability to pass at conference in an attempt to control the opinion assignment in a significant minority of cases.

At the same time, one might think that Chief Justice Burger's passes would become a self-defeating strategy as the associate justices would come to resent what they saw as Burger's efforts to control the agenda. Justice Douglas intimated that possibility when he said, "It is not for us in the minority to outwit Byron by saying 'I reserve my vote' and then recast it to control the assignment. That only leads to a frayed and bitter Court full of needless strains and quarrels" (Justice William O. Douglas, quoted in Epstein and Knight 1998:126). Other justices, however, are somewhat limited in their ability to give voice to their disenchantment with the chief's behavior. Short of voting contrary to their sincere preferences to support a competing outcome, and thereby dislodging the chief from the majority, justices have one potential weapon to defeat the chief's strategy: they can refuse to support the majority opinion. That is, justices may concur in the result announced by the majority opinion without joining that opinion. This practice might deprive an opinion of enough support and therefore render it a plurality opinion with less precedential weight. We do not find

35 We obtained the conference vote data from Powell's docket sheets and assignment data from Spaeth (2001b). Note that we do not have sufficient data to test whether the same effects hold for the associate justices or for Chief Justice Rehnquist. Thus, our analysis in this section focuses only on Chief Justice Burger. Nonetheless, the results are compelling and insightful. 
evidence that justices employed this retaliatory scheme to punish Burger's passes. Indeed, when Burger did not pass, the mean number of separate concurrences in a case was 0.507 , while this number only increased to 0.562 when he did pass $(p=0.28)$. In short, while Burger may have used passing in a strategic manner, his colleagues did not overtly punish him for doing so.

\section{Conclusion}

Here, for the first time, we provide generalizable systematic evidence that Chief Justice Burger and Chief Justice Rehnquist, as well as the senior associates during these years (Justices Douglas and Brennan), used their ability to pass at conference in an attempt to control the opinion assignment in a significant minority of cases. While we certainly focus on a rare event, its significance should not be diminished because it happens so rarely. Indeed, passing can and does help the chief (and senior associate) as they try to move policy as close as possible to their preferred goals.

Generally, this study makes several contributions to the study of collegial decisionmaking by judges. First, it addresses an important stage of the Supreme Court's decisionmaking process about which scholars know relatively little. The conference vote is germane for at least two reasons: (1) it determines which justice will assign the majority opinion and thus has potential agenda-setting effects, and (2) it sets parameters within which the majority opinion author will write his or her draft of the Court's opinion. Existing accounts of conference voting come largely from journalistic accounts (Woodward \& Armstrong 1979) or from writings by justices (Rehnquist 1987) and former clerks (Lazarus 1999). In addition, the scholarly studies that touch upon conference procedures and votes mainly consist of discussions of the voting in particular cases (e.g., Dickson 2001; Schwartz 1990, 1993, 1996; Murphy 1964; but see Brenner \& Palmer 1995; Danelski 1961). ${ }^{36}$ Thus, by offering systematic evidence of how justices behave when they initially discuss and vote on the merits of cases, we provide valuable insights into a process largely unseen by scholars.

Second, this article investigates the important phenomenon of sophisticated voting. A sophisticated vote requires three things: a multistage voting process, adequate information about other voters' preferences, and knowledge of the agenda. When these conditions exist, we expect justices to cast sophisticated votes by

36 Many scholars, of course, have explored voting fluidity, that is, those instances where justices change positions between conference and the final vote on the merits (see, e.g., Dorff \& Brenner 1992; Hagle \& Spaeth 1991; Brenner 1982; Howard 1968; Maltzman \& Wahlbeck 1996). 
making decisions at earlier stages of the judicial game based on likely outcomes at later stages. Of particular interest to us here is sophisticated insincerity, in which a justice votes against his or her preferred outcome at one decisionmaking stage in anticipation of that choice yielding a better outcome at a later stage of the game.

Because the CJ has priority in opinion assignment, and because he votes first at conference, he has a strategic incentive to pass when he is uncertain about whether he will be in the winning coalition. Since casting a sincere vote may leave him unable to assign the opinion, the chief may reserve his vote if he is unsure of which position will command a majority once all votes are cast. Passing at conference thus has strategic value because it allows the chief (or SAJ) to reorder the voting sequence such that he votes last instead of first, and to thus reap informational advantages. In essence, he passes in order to put himself in a position to vote with the majority and, in turn, to have greater leverage over the legal rule being crafted in the case. Our results indicate that passing can and does help the chief (and, to a lesser extent, the SAJ) as justices try to move policy as close as possible to their preferred goals.

We also shed light on the ongoing theoretical debate about the nature of Supreme Court decisionmaking. The attitudinal model acknowledges that Supreme Court justices act interdependently except when it comes to the final vote on the merits (Segal \& Spaeth 2002). However, at the final stage, when deciding whether to affirm or reverse, attitudinalists argue that justices - who are appointed for life, whose decisions cannot be reversed by a higher court, and who lack higher political ambition — vote exactly as their own beliefs and values dictate. In contrast, strategic accounts posit that every decision made by the justices, including the final votes on the merits, is ripe for strategic behavior because every choice the justices make is an interdependent one (Epstein \& Knight 1998; Hoekstra \& Johnson 2003; Maltzman et al. 2000).

More specifically, we address this theoretical debate by focusing on a stage of decisionmaking - the conference vote on the merits - where the attitudinal and strategic models' expectations diverge. Indeed, the fact that the chief (and the SAJ) passes in an attempt to reach his preferred outcomes suggests that justices do not exclusively vote based on their preferences. While this may be circumstantial rather than direct evidence, it is good evidence nonetheless. Thus, this article provides important evidence that the attitudinal model may not provide a fully accurate picture of how Supreme Court justices vote on the merits.

Finally, our findings, combined with other research that finds a link between strategic interaction and Supreme Court decisionmaking, have clear implications for decisionmaking on collegial courts beyond the United States. In particular, this study highlights 
the importance of institutional rules, such as voting procedures, to the work of collegial courts. Certainly our study focuses on one aspect of how the U.S. Supreme Court operates, but one can infer that policy outcomes can be affected by a judge who manipulates the institutional rules that govern a court. Rules may vary from court to court, but their impact on the resulting legal policy remains consistent.

\section{References}

Austen-Smith, (1987) "Sophisticated Sincerity: Voting on Endogenous Agendas," 81 American Political Science Rev. 1323-30.

Banks, Jeffrey (1985) "Sophisticated Voting Outcomes and Agenda Control," 1 Social Choice and Welfare 295-306.

Baum, Lawrence (2001) The Supreme Court, 7th ed. Washington, D.C.: Congressional Quarterly Press.

Blalock, Hubert (1979) Social Statistics, 2nd ed. New York: McGraw-Hill.

Brace, Paul R., \& Hall Melinda Gann (1997) "The Interplay of Preferences, Case Facts, Context, and Rules in the Politics of Judicial Choice," $59 \mathrm{~J}$. of Politics 1206-31.

Brennan, William J. Jr. (1960) "State Court Decisions and the Supreme Court," 31 Pennsylvania Bar Association Q. 393-407.

Brenner, Saul (1982) "Fluidity on the Supreme Court: 1956-1967," 26 American J. of Political Science 388-90.

Brenner, Saul, \& Timothy M. Hagle (1996) "Opinion Writing and the Acclimation Effect," 18 Political Behavior 235-61.

Brenner, Saul, \& Jan Palmer (1995) "The Law Clerks' Recommendations and the Conference Vote on-the-Merits on the U.S. Supreme Court," 18 Justice Systems J. 185-97.

Caldeira, Gregory A., et al. (1999) "Sophisticated Voting and Gate-Keeping in the Supreme Court," $15 \mathrm{~J}$. of Law, Economics, and Organization 549-72.

Calvert, Randall L., \& Richard F. Fenno Jr. (1994) "Strategy and Sophisticated Voting in the Senate," $56 \mathrm{~J}$. of Politics 349-76.

Clark, Tom C. (1959) "Internal Operation of the United States Supreme Court," 43 Judicature 45-51.

Danelski, David J. (1961) "The Influence of the Chief Justice in the Decisional Process of the Supreme Court," in W. Murphy \& C. H. Pritchett, eds., Courts, Judges, and Politics. New York: Random House.

Denzau, Arthur T., et al. (1985) "Farquharson and Fenno: Sophisticated Voting and Home Style," 79 American Political Science Rev. 1117-34.

Dickson, Del (2001) The Supreme Court in Conference (1940-1985). Oxford: Oxford Univ. Press.

Dorff, Robert H., \& Saul Brenner (1992) "Conformity Voting on the United States Supreme Court,” $54 \mathrm{~J}$. of Politics 762-75.

Epstein, Lee, \& Jack Knight (1998) The Choices Justices Make. Washington, D.C.: Congressional Quarterly Press.

Epstein, Lee, \& Joseph F. Kobylka (1992) The Supreme Court and Legal Change: Abortion and the Death Penalty. Chapel Hill: Univ. of North Carolina Press.

Epstein, Lee, \& Carol Mershon (1996) "Measuring Political Preferences," 40 American J. of Political Science 261-94.

Epstein, Lee, \& Olga Shvetsova (2002) "Heresthetical Maneuvering on the U.S. Supreme Court," 14 J. of Theoretical Politics 93-122. 
Epstein, Lee, et al. (1996) "The Claim of Issue Creation on the U.S. Supreme Court," 90 American Political Science Rev. 845-52.

-, et al. (1998) "Do Political Preferences Change? A Longitudinal Study of U.S. Supreme Court Justices," $60 \mathrm{~J}$. of Politics 801-18.

—_ et al. (2001) "The Role of Constitutional Courts in the Establishment and Maintenance of Democratic Systems of Government," 35 Law \& Society Rev. 117-63.

Farquharson, Robin (1969) Theory of Voting. New Haven, CT: Yale Univ. Press.

Friedrich, Robert J. (1982) "In Defense of Multiplicative Terms in Multiple Regression Equations," 26 American J. of Political Science 797-833.

Gibson, James L. (1997) United States Supreme Court Judicial Database, Phase II: 1953-1993. Ann Arbor, MI: Inter-University Consortium for Political and Social Research.

Hagle, Timothy M., \& Harold J. Spaeth (1991) "Voting Fluidity and the Attitudinal Model of Supreme Court Decision Making," 44 Western Political Q. 119-28.

Hansford, Thomas G., \& David F. Damore (2000) "Congressional Preferences, Perceptions of Threat, and Supreme Court Decision Making," 28 American Politics Q. 490-510.

Helmke, Gretchen (2002) "The Logic of Strategic Defection: Court-Executive Relations in Argentina Under Dictatorship and Democracy," 96 American Political Science Rev. 291-303.

- (2003) "Checks and Balances by Other Means: Strategic Defection and Argentina's Supreme Court in the 1990s," 35 Comparative Politics 213-30.

Hoekstra, Valerie, \& Timothy R. Johnson (2003) "Delaying Justice: The Supreme Court's Decision to Hear Rearguments," 56 Political Research Q. 351-60.

Howard, J. Woodford (1968) "On the Fluidity of Judicial Choice," 62 American Political Science Rev. 43-56.

Huber, John D. (1996) "The Vote of Confidence in Parliamentary Democracies," 90 American Political Science Rev. 269-82.

Iaryczower, Matias, et al. (2002) "Judicial Independence in Unstable Environments, Argentina 1935-1998," 46 American J. of Political Science 699-716.

Jenkins, Jeffrey, \& Michael Munger (2003) "Investigating the Incidence of Killer Amendments in Congress," $65 \mathrm{~J}$. of Politics 498-517.

Johnson, Timothy R. (2004) Oral Arguments and Decision Making on the United States Supreme Court. Albany, NY: SUNY Press.

King, Gary, \& Langche Zeng (2001a) "Logistic Regression in Rare Events Data," 9 Political Analysis 137-63.

—_ (2001b) "Explaining Rare Events in International Relations," 55 International Organization 693-715.

Kramer, Gerald H. (1972) "Sophisticated Voting Over Multidimensional Choice Spaces," 2 J. of Mathematical Sociology 165-80.

Krehbiel, Keith, \& Rivers Douglas (1990) "Sophisticated Voting in Congress: A Reconsideration," $52 \mathrm{~J}$. of Politics 548-78.

Lazarus, Edward (1999) Closed Chambers: The Rise, Fall, and Future of the Modern Supreme Court. New York: Penguin Books.

Maltzman, Forrest, et al. (2000) Crafting Law on the Supreme Court: The Collegial Game. New York: Cambridge Univ. Press.

Maltzman, Forrest, \& Paul J. Wahlbeck (1996) "Strategic Policy Considerations and Voting Fluidity on the Burger Court," 90 American Political Science Rev. 581-92.

Martin, Andrew D. (2001) "Congressional Decision Making and the Separation of Powers," 95 American Political Science Rev. 361-78.

McGuire, Kevin T., \& Barbara Palmer (1995) "Issue Fluidity on the U.S. Supreme Court," 89 American Political Science Rev. 691-702.

- (1996) "Issues, Agendas, and Decision Making on the Supreme Court," 90 American Political Science Rev. 853-65. 
McKelvey, Richard D., \& Richard G. Niemi (1978) "A Multistage Game Representation of Sophisticated Voting for Binary Procedures," $18 \mathrm{~J}$. of Economic Theory 1-22.

Murphy, Walter J. (1964) Elements of Judicial Strategy. Chicago: Univ. of Chicago Press.

Nagel, Jack H. (1993) "Populism, Heresthetics and Political Stability: Richard Seddon and the Art of Majority Rule," 23 British J. of Political Science 139-74.

O'Connor, Sandra Day (1985) Memorandum to Chief Justice Warren E. Burger, March 4. Papers of William J. Brennan, Jr., Library of Congress Manuscript Division, Washington, D.C.

Powell, Lewis F. Jr. (1978) Memorandum to Chief Justice Burger, April 29. Papers of Justice Lewis F. Powell Jr. Washington \& Lee Law Library, Lexington, VA.

Rasch, Bjorn Erik (2000) "Parliamentary Floor Voting Procedures and Agenda Setting in Europe," 25 Legislative Studies Q. 3-23.

Rehnquist, William H. (1987) The Supreme Court: How It Was, How It Is. New York: Quill. (2001) The Supreme Court. Revised ed. New York: Knopf.

Riker, William H. (1962) The Theory of Political Coalitions. New Haven, CT: Yale Univ. Press.

- (1983) "Political Theory and the Art of Heresthetics," in A. F. Finifter, ed., Political Science: The State of the Discipline. Washington, D.C.: American Political Science Association.

(1984) "The Heresthetics of Constitution-Making: The Presidency in 1787, with Comments on Determinism and Rational Choice," 78 American Political Science Rev. $1-16$.

—_ (1986) The Art of Political Manipulation. New Haven, CT: Yale Univ. Press.

(1990) "Heresthetic and Rhetoric in the Spatial Model," in J. M. Enelow \& M. J. Hinich, eds., Advances in the Spatial Theory of Voting. New York: Cambridge Univ. Press.

Riker, William H. (1993) A History of the Supreme Court. New York: Oxford Univ. Press. (1996) Decision: How the Supreme Court Decides Cases. New York: Oxford Univ. Press.

Rohde, David W., \& Harold J. Spaeth (1976) Supreme Court Decision Making. San Francisco: W. H. Freeman.

Sala, Brian R., \& James F. Spriggs II. (2004) "Designing Tests of the Supreme Court and the Separation of Powers," 57 Political Research Q. 197-208.

Schwartz, Bernard (1990) The Ascent of Pragmatism: The Burger Court in Action. Reading, MA: Addison-Wesley.

Segal, Jeffrey A., \& Harold J. Spaeth (2002) The Supreme Court and the Attitudinal Model Revisited. New York: Cambridge Univ. Press.

Segal, Jeffrey A., et al. (1995) "Ideological Values and the Votes of U.S. Supreme Court Justices Revisited," $57 \mathrm{~J}$. of Politics 812-23.

Spaeth, Harold J. (2001a) United States Supreme Court Judicial Database, 1953-2000 Terms. East Lansing: Michigan State Univ. (2001b) The Burger Court Judicial Database: 1969-1985 Terms. East Lansing: Michigan State Univ.

Spriggs, James F. II, \& Thomas G. Hansford (2001) "Explaining the Overruling of U.S. Supreme Court Precedent," 63 J. of Politics 1091-111.

Spriggs, James F. II, et al. (1999) "Bargaining on the U.S. Supreme Court: Justices' Responses to Majority Opinion Drafts," $61 \mathrm{~J}$. of Politics 485-506.

Tomz, Michael, et al. (1999) RELOGIT: Rare Events Logistic Regression. Version 1.1. Harvard University, Cambridge, available at http://gking.harvard.edu/ (accessed February 16, 2005).

Vanberg, George (2001) "Legislative-Judicial Relations: A Game-Theoretic Approach to Constitutional Review," 45 American J. of Political Science 346-61.

Volden, Craig (1998) "Sophisticated Voting in Supermajoritarian Settings," $60 \mathrm{~J}$. of Politics 149-73. 
Wahlbeck, Paul J. (1997) “The Life of the Law: Judicial Politics and Legal Change," $59 \mathrm{~J}$. of Politics 778-802.

Woodward, Bob, \& Scott Armstrong (1979) The Brethren: Inside the Supreme Court. New York: Avon Books.

\section{Case Cited}

Spencer v. South Carolina Tax Commission, 471 U.S. 82 (1985).

Timothy Johnson is an Assistant Professor in the Department of Political Science at the University of Minnesota. He received his Ph.D. from Washington University in St. Louis in 1998. His research interests include American politics, judicial politics, Supreme Court decisionmaking, oral arguments, executive/judiciary relations, the evolution of precedent, and third party politics. He has published articles in the American Political Science Review, American Politics Research, Journal of Politics, and Political Research Quarterly. He coauthored the book Religious Institutions and Minor Parties in the United States (Praeger Press 1999, with Chris Gilbert, David A. M. Peterson, E Paul Djupe), and is the author of Oral Arguments and Decision Making on the U.S. Supreme Court (SUNY Press 2004).

James F. Spriggs II is an Associate Professor in the Department of Political Science at the University of California, Davis. Spriggs received his Ph.D. from Washington University in St. Louis in 1994. His research interests in American politics focus on the study of judicial process and politics. He is especially interested in the influence of institutional rules on the choices that judges make as they craft legal doctrine. He has published articles in the American Journal of Political Science, Journal of Politics, Political Research Quarterly, American Politics Research, and Law \& Society Review. His book on the nature and timing of the U.S. Supreme Court's interpretation of precedent (with Thomas G. Hansford, University of South Carolina) is forthcoming from the Princeton University Press.

Paul J. Wahlbeck is Associate Professor of Political Science at George Washington University. He has published articles in numerous journals, including American Political Science Review, American Journal of Political Science, and Law \& Society Review. His book, coauthored with Forrest Maltzman and James Spriggs, Crafting Law on the Supreme Court, was published by Cambridge University Press. Wahlbeck served as director of the Law and Social Science Program at the National Science Foundation from 2001 to 2003. 
